\title{
On some Young Specimens of Centrolophus pompilus (Art.) from the Coast of Cornwall.
}

\author{
By
}

\section{Ernest w. L. Holt.}

ON the 24th June, 1891, a mackerel boat, which had been fishing off the Runnistone, brought in several fish of the above species. They excited a good deal of interest among the local fishermen, to whom they were quite unknown. A coastguardsman, who had seen them abroad, I forget where, declared them to be "pilot-fish," a diagnosis with which some of the fishermen, to whom the true pilotfish, Naucrates ductor, appeared to be known, could by no means agree. It appears, however, that from a certain similarity of habits the name is occasionally applied to the form before us, usually known to British naturalists as the black-fish.

I believe that about six or eight black-fish were brought ashore on this occasion, of which, by the kindness of Mr. J. C. James of Newlyn, I managed to secure four. They were all small specimens, the total lengths being $13 \frac{3}{4}$ inches, $13 \frac{1}{2}$ inches, $12 \frac{5}{8}$ inches, and $12 \frac{5}{8}$ inches. Before preserving them I examined the contents of their stomachs, which consisted of a considerable number of young pollack, about 3 inches long; in fact, the stomachs were quite distended with them. I also endeavoured to ascertain their sex, and concluded that they were all immature males. Hermaphroditism has been recorded by Syrski in this species (cf. Max Weber, U. Hermaph. b. Fischen. Ned. Tijdsch., Jaarg. v, 1884, p. 37),* but it does not appear whether this is a normal or abnormal condition.

The colouration of the black-fish appears to be highly variable. Couch draws special attention to this point, noting the difference between Risso's description of Mediterranean specimens and the condition in British examples that had come under the notice of himself and earlier observers. That this, however, is not wholly attributable to climatic influences, as Couch seems to have supposed, may be inferred from an examination of Bonaparte's figure (Faun,

* I am indebted to Prof. G. B. Howes for this reference. 
Ital. Pesc.), in which the colours are shown nearly as dark as those met with in British specimens. Indeed, the colours in my own specimens bear a closer resemblance to those in Bonaparte's figure than to the condition described by Couch, and the dull neutral hue shown in his figure (British Fishes, vol. ii, pl. xc) is altogether wanting, though the example from which it was drawn was about the same size as my own. Of the uniform brown colour, stated by Day (Fish. Gt. Brit., vol. i, p. 112) to be usual in this species, there is no trace; but Buckland's description is fairly applicable.

The following notes were taken before the fish were placed in spirit. In the two larger specimens the head is a very dark violetgrey above, minute lighter specks marking the muciferous pores; between the eye and the upper jaw the colour is sapphire blue,* due to irridescence, with grey pores. Similarly, the under side of the head is blue, dark grey bands marking the course of the hyoid and the edge of the opercular membrane. The iris is white, speckled with grey, becoming yellowish towards its inner margin, and grey towards the circumference. The gill covers are dark violet-grey with lighter streaks. The body is a violet black along the dorsal region, shading very gradually to a silver grey ventrally, almost white on the ventral surface of the abdomen. Small ovoidal silver-grey flecks occur on the sides above and below the lateral line, most abundantly in the deepest region of the fish, $i . e$. at about the level of the commencement of the dorsal fin. In the largest of the two specimens these flecks are very faintly marked.

The dorsal fin is black, dotted with minute grey specks about the base, due to the fact that the scales covering this region are grey with black edges. No such conspicuously lighter band, as is shown in Day's figure (op. cit., pl. xl, fig. 2), occurs in any of my specimens. The base of the pectoral is grey, the distal region black. The pelvic has black rays, and a bluish-grey membrane. In the anal, the basal region is silver grey, shading into black at the distal margin.

The colours of the two smaller specimens agree generally with the above description, but are paler. In one, the greater part of the body below the lateral line is silver grey. There is no blue iridiscence on the cheeks of either, and the lower jaw is very pale and lacks the darker bands. The flecks on the sides are more plainly marked than in the larger specimens, and are probably of a transitory nature, disappearing as the fish increases in size. Day notes that these markings, which he describes as yellow, are absent in some specimens, but does not mention the sizes of the fish he

* Couch notes that whilst he was drawing his specimen the side on which it was laid turned to a fine blue. 
examined. Risso speaks of young examples having dark transverse bands, so that it appears that, as is usual in fishes, there are several phases of colouration.

The records of the occurrence of the black-fish on the British coasts, as collated by Day, are pretty numerous, the greater number having come, like the specimens before us, from the coast of Cornwall; from the same authority we learn that its range extends southwards to Madeira, and into the Mediterranean, whilst it has occurred so far north as the coast of Northumberland.

Day quotes an interesting observation of Mr. Dunn, that of about a dozen taken near Mevagissey, every one could be traced to the neighbourhood of a large fish, generally a shark. The only shark that I heard of was a young thresher, Alopias vulpes (Gmel.), about 15 feet long, which was brought into Penzance a few days previously from the neighbourhood of the Scilly Islands, and exhibited in the market at a penny per head as a young whale. The Runnistone is no great distance from the Scillies, but six or eight black-fish seem rather a large escort for one shark, and it might be supposed that the habits of the thresher would render it a companion more lively than agreeable. It may be mentioned that the stomach of the thresher contained about a bucketful of pilchards. 